\title{
Clinical and electrophysiological characteristics of spasticity in patients with multiple sclerosis
}

\author{
N.V. Domres \\ O.O. Bohomolets National Medical University, Kyiv, Ukraine
}

\begin{abstract}
Objective: Determining the relationship between clinical and electrophysiological features of spasticity in patients with multiple sclerosis. Materials and methods. We examined 100 patients with multiple sclerosis with spasticity. The Modified Ashworth Scale was used to quantify the severity of changes in muscle tone. Electroneuromyography was performed on a «Nihon Kohden» device using standard non-invasive stimulation techniques in the upper and lower extremities. Results. The level of average spasticity in patients on the Modified Ashworth Scale ranged from 0.4 to 3.0 points. The level of spasticity of individual muscle groups was found to be significantly different in the three groups of different types of multiple sclerosis. The level of total spasticity in patients with multiple sclerosis was statistically significantly increased in patients with severe disability and had a direct mean correlation with the degree of Expanded Disability Status Scale $(r s=0.649 ; p<0.05)$. Assessment of the function of $n$. medianus and $n$. tibialis motor fibers revealed significant changes in $M$-amplitude. Conclusions. The highest values of mean spasticity are observed in patients with secondary-progressive multiple sclerosis, pyramidal and bowel/bladder functional systems have the strongest correlation with the level of total spasticity ( $r s=0.712$ and $0.666 ; p<0.05$, respectively). Among the muscle groups of the lower extremities, the average score of spasticity is the highest in the knee extensors in secondary-progressive multiple sclerosis patients $-2.49 \pm 0.19$ points, and the lowest in patients with relapsing-remitting multiple sclerosis for foot flexors $1.08 \pm 0.06(p<0.01)$. The main electrophysiological indicator of early manifestations of muscle spasticity of the upper and lower extremities in patients with multiple sclerosis is a decrease in the amplitude of the M-response $(p<0.01)$.
\end{abstract}

Key words: multiple sclerosis, spasticity, Modified Ashworth Scale, electroneuromyography, M-amplitude.

\section{Background}

Spasticity is a typical symptom of multiple sclerosis (MS), which can occur in $60-85 \%$ of patients [1]. In the last decade, most research on MS is dedicated to the problem of early diagnosis, specifics of the types of course and activity of the disease, neuroimaging methods of diagnosis, evaluation of the effectiveness of methods of pathogenetic treatment of MS. Research and quantification of the level of spasticity, especially in the early stages of the disease, is not given due attention. Scale measurement scales are almost never used in medical practice.

Clinically, patients with MS have difficulty in voluntary movements due to increased muscle tone in the leg extensors and flexors [2], and the incidence of spasticity in the leg muscles is almost twice as high as in arm muscles [3]. Stiffness is most common in the muscles of the legs, thighs and buttocks. Some patients are less likely to experience back muscle stiffness [4]. All of these muscles are responsible for maintaining the vertical position of the human body in space and balance during movement [5].

There are two types of severe lower limb spasticity in MS:

- flexor spasticity, which is most common in the muscles of the back of the thigh and the flexors of the thigh. In these cases, thigh and knee are difficult to straighten;

- extensor spasticity, in which the quadriceps and abductors of the thigh are involved (on the anterior and inner surfaces). As a result, the thighs and knees remain straight, while the patient finds it difficult to bring the legs together or cross the legs [6].

The clinical manifestations, as well as the pathophysiological characteristics of the upper motor neuron lesions in MS, in particular spasticity in both the lower and upper extremities, remain insufficiently studied. Therefore, the assessment of spasticity using electrophysiological diagnostic methods is relevant. Electroneuromyography as a method to clarify the degree of damage and the extent of involvement in the pathological process of muscle tissue, is mainly used in medical practice for the differential diagnosis of MS. According to F. Biering-Sørensen et al. (2006) and A.J. Mitchell et al. $(2005)[7,8]$, the results of the electrophysiological study are not specific to spasticity. The literature notes that there is a medium correlation between electrophysiological studies and clinical scales. Late electrophysiological phenomena have been most frequently evaluated in studies: the H-reflex, as increased excitability of a-motoneurons is an important mechanism of spasticity $[9,10]$. The importance of early electrophysiological phenomena (amplitude and latency of the M-response) in the diagnosis of spasticity in MS has not been given enough attention.

Meanwhile, the identification of clinical data characterizing spasticity with the results of electroneuromyographic examination and identification of early electrophysiological phenomena of spasticity will significantly expand the understanding of the mechanisms of spastic paresis and will contribute to the development of new treatments.

Objective: to determine the relationship between clinical and electrophysiological characteristics of spasticity in patients with MS.

\section{Materials and methods}

We examined 100 patients (47 men and 53 women) with a clinically reliable diagnosis of MS who were hospitalized in the Kyiv City Center of MS. The diagnosis of MS was established using international McDonald criteria [11].

Assessment of neurological deficit was performed on the Expanded Disability Status Scale (EDSS) [12-14]. Patients with an EDSS level of 3 to 7 points were included in the study.

The Modified Ashworth Scale (MAS) $[15,16]$ was used to quantify the severity of changes in muscle tone.

Muscle tone was assessed in extensor and flexor muscle groups, with a score ranging from 0 to 3 (the maximum MAS spasticity score is 4 , but there were no such patients). We calculated the mean and total spasticity scores in patients with MS.

The mean score of spasticity of the lower extremities was calculated as the arithmetic mean of spasticity scores in 4 groups of muscles of the right and left lower extremities (thigh adductors, knee flexors, knee extensors, feet). The average score of spasticity in our study ranged from 0.4 to 3.0 points. Patients were divided into 3 groups with different levels of spasticity depending on the mean score. The first group consisted of patients with a mild level of spasticity (0.4-1.4 points) -32 patients, the second with a medium level of spasticity (1.5-2.0 points) -45 patients, and the third with a severe level of spasticity ( $2.1-3.0$ points $)-23$ patients.

The total spasticity score was calculated by adding the spasticity scores per the MAS in 4 lower limb muscle groups (thigh adductors, knee flexors, knee extensors, feet) and 2 upper limb muscle groups (forearm flexors and extensors). The total spasticity score in patients ranged from 4 to 26 points. Depending on the total score of spas- 
ticity, patients were divided into two groups with a total score of 4-12 points (58 patients) and $13-26$ points ( 42 patients).

Electroneuromyography was performed on a «Nihon Kohden» device. In our study, a stimulating non-invasive standard technique was used in the following areas: $\mathrm{n}$. medianus and $\mathrm{n}$. tibialis motor fibers; $\mathrm{n}$. medianus sensitive fibers; $\mathrm{n}$. medianus and $\mathrm{n}$. tibialis F-wave; H-reflex.

The following indicators were evaluated:

- when examining the motor and sensory fibers $n$. medianus and n. tibialis: amplitude of M-response (mV), latency (ms), interval (ms), conduction velocity $(\mathrm{m} / \mathrm{s})$.

- when examining F-wave of $\mathrm{n}$. medianus and $\mathrm{n}$. tibialis: M-latency (ms), M-amplitude (mV), F-frequency (\%), average F-latency (ms), average F-amplitude (mV).

- when examining H-reflex: M-latency (ms), maximum $\mathrm{M}(\mathrm{mV})$, maximum $\mathrm{H}(\mathrm{mV}), \mathrm{M} / \mathrm{H}$ ratio, $\mathrm{H}$-latency (ms).

The following software was used to process the digital material:

- Microsoft Excel version 16.0.12527.21236 (Microsoft Corporation, USA);

- Statistica 12.0 (StatSoft Inc., USA).

\section{Results and discussion}

We analyzed the level of mean and total spasticity per MAS in MS patients.

The level of spasticity in patients on the MAS ranged from 0.4 to 3.0 points. The average score of spasticity was $1.68 \pm 0.06$ points. The group with the lowest average score of spasticity (0.4-1.4) consisted of 32 patients, the group with a score of 2.1-3.0 consisted of 23 patients. The largest group consisted of 45 patients with a mean score of 1.5-2.0 (Fig. 1).

Figure 1 Distribution of patients by level of spasticity (average score)

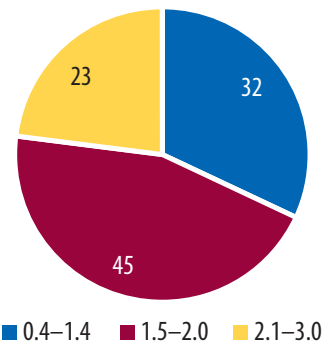

The distribution of patients by groups depending on sex, age, disease duration and EDSS level in groups of different levels of spasticity are presented in Table 1.

Table 1 General characteristics of patients depending on the level of average spasticity

\begin{tabular}{|c|c|c|c|c|c|}
\hline \multirow{2}{*}{\multicolumn{2}{|c|}{ Indicator }} & \multicolumn{3}{|c|}{$\begin{array}{l}\text { Groups of patients by level of spasticity } \\
\text { (average score) }\end{array}$} & \multirow{2}{*}{ Total } \\
\hline & & $\begin{array}{l}0.4-1.4 \\
(\mathrm{n}=32)\end{array}$ & $\begin{array}{l}1.5-2.0 \\
(n=45)\end{array}$ & $\begin{array}{l}2.1-3.0 \\
(n=23)\end{array}$ & \\
\hline \multirow[t]{2}{*}{ Sex } & Male & 12 & 22 & 13 & 47 \\
\hline & Female & 20 & 23 & 10 & 53 \\
\hline \multirow[t]{3}{*}{ Age, years } & 24-35 & 9 & 9 & 4 & 22 \\
\hline & $36-49$ & 17 & 19 & 9 & 45 \\
\hline & $52-71$ & 6 & 17 & 10 & 33 \\
\hline \multirow{3}{*}{$\begin{array}{l}\text { Disease } \\
\text { duration, years }\end{array}$} & $1-9$ & 11 & 14 & 2 & 27 \\
\hline & 10-19 & 20 & 25 & 10 & 55 \\
\hline & $20-40$ & 1 & 6 & 11 & 18 \\
\hline \multirow[t]{3}{*}{ EDSS } & $3.0-3.5$ & 6 & 5 & 1 & 12 \\
\hline & $4.0-5.0$ & 19 & 21 & 11 & 51 \\
\hline & $5.5-7.0$ & 7 & 19 & 11 & 37 \\
\hline
\end{tabular}

We analyzed the level of average spasticity in groups of patients with different types of MS. In our study, there were 61 patients with relapsing-remitting MS (RRMS), 27 patients with secondary-pro- gressive MS (SPMS), and 12 patients with primary progressive MS (PPMS). In patients with different types of course, the average level of spasticity was statistically different in each of the groups $(p<0.01)$ as determined using the Kruskal - Wallis test for three groups of nonparametric values. The highest level of average spasticity was observed in patients with SPMS $-1.87 \pm 0.13$ points, the lowest in patients with RRMS (1.64 \pm 0.10 points). In patients with PPMS, the level of mean spasticity was $1.86 \pm 0.22$ points (Table 2 ).

Table 2 Average spasticity in patients with different course of the disease

\begin{tabular}{|c|c|c|c|c|}
\hline Average spasticity & $\begin{array}{l}\text { RRMS } \\
(\mathrm{n}=61)\end{array}$ & $\begin{array}{c}\text { SPMS } \\
(\mathrm{n}=27)\end{array}$ & $\begin{array}{l}\text { PPMS } \\
(n=12)\end{array}$ & $\mathbf{p}$ \\
\hline Average score & $1.64 \pm 0.10$ & $1.87 \pm 0.13$ & $1.86 \pm 0.22$ & \multirow{3}{*}{$<0.01$} \\
\hline$Q_{1}-Q_{3}$ & $1.00-1.50$ & $1.50-2.00$ & $1.00-2.00$ & \\
\hline $\mathrm{Me}$ & 1.50 & 2.00 & 1.81 & \\
\hline
\end{tabular}

We assessed the level of spasticity of three study groups of patients with different course of disease in different muscle groups: hip adductors, knee flexors, knee extensors, foot flexors (Fig. 2).

Figure 2 Average spasticity of different muscle groups in patients with different disease course $(p<0.01)$

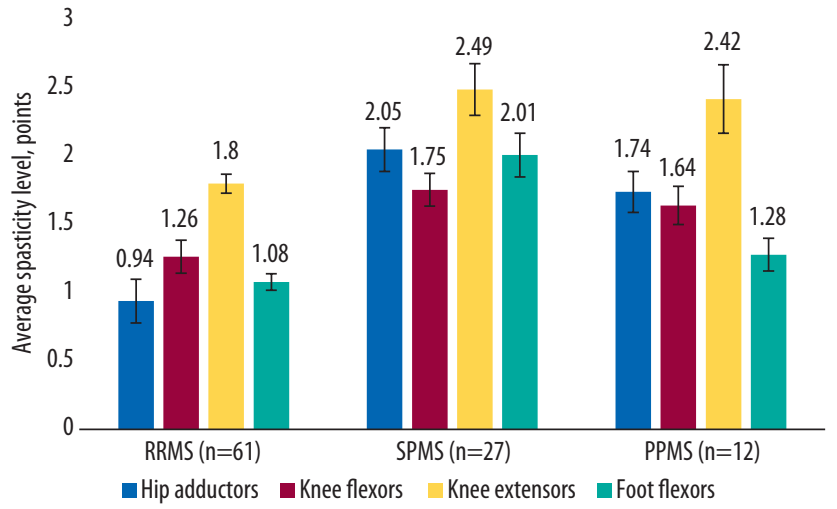

The level of spasticity of individual muscle groups was found to be significantly different in the three study groups. The greatest spasticity is observed in the knee extensors with the corresponding values, which corresponds to the literature data [17]. For RRMS, average indicators of spasticity were $0.99 \pm 0.13$ (hip adductors), $1.29 \pm 0.04$ (knee flexors), $1.81 \pm 0.11$ (knee extensors), $1.09 \pm 0.10$ (foot flexors) points for the right leg and $0.89 \pm 0.14,1.24 \pm 0.09,1.79 \pm 0.15$, $1.07 \pm 0.08$ points, respectively, for the left leg. In patients with PPRS, the average spasticity was higher, specifically in the right leg in hip adductors it was $1.79 \pm 0.18$, in knee flexors $1.65 \pm 0.14$, in knee extensors $2.45 \pm 0.31$, in foot flexors $1.29 \pm 0.34$ and $1.69 \pm 0.14,1.63 \pm 0.24$, $2.39 \pm 0.29,1.27 \pm 0.32$ for the left leg, respectively. The highest mean spasticity was in patients with SPMS in the extensor muscles. In the right leg in hip adductors it was $2.04 \pm 0.13$, in knee extensors $2.56 \pm 0.18$, in knee flexors $1.72 \pm 0.11$, in foot flexors $-1.97 \pm 0.13$, in the left leg $2.06 \pm 0.19,2.42 \pm 0.19,1.79 \pm 0.13,2.05 \pm 0.16$, respectively.

The mean values for both limbs were the highest in the knee extensors in patients with SPMS $-2.49 \pm 0.19$ points, and the lowest in patients with RRMS in foot flexors - 1.08 \pm 0.06 .

Because in many patients spasticity was seen in only one limb or muscle group, and in other groups it was 0 points, this affected the mean score. Therefore, for a more detailed assessment of spasticity, we decided to additionally calculate the total spasticity score as the sum of all spasticity scores in all muscle groups (including the upper extremities). Thus, patients who had high spasticity in 1-2 muscle groups and 0 points in other groups had higher scores than patients who had uniform scores in all muscle groups. Total spasticity score ranged from 4 to 26 points. We divided the patients into 2 groups: $4-12$ points and $13-26$ points.

We also analyzed the level of total spasticity in groups with different levels of disability of patients per EDSS scale. The highest level of total spasticity score was in the group of patients with the high- 
est degree of disability - 5.5-7.0 points (37 patients) and averaged $15.26 \pm 0.77$ points, the lowest in patients ( 12 patients) with EDSS of $3.0-3.5$ points ( $6.29 \pm 0.82$ points). Patients with an average EDSS level of 4.0-5.0 points (51 patients) corresponded to an average level of spasticity of $11.03 \pm 0.58$ points (Fig. 3). The difference was statistically significant as determined using the Kruskal — Wallis test $(\mathrm{p}<0.0001)$.

Figure 3 Total spasticity in patients with MS with varying degrees of EDSS $(p<0.0001)$

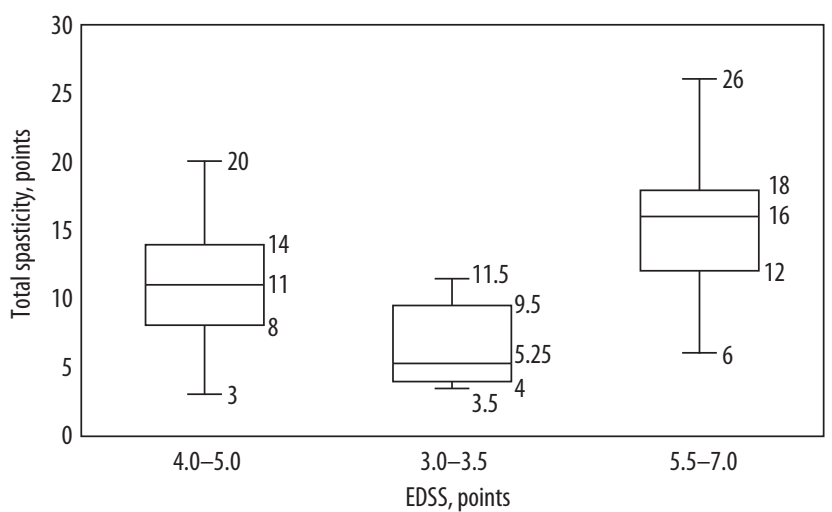

The results showed that the level of total spasticity in patients with MS was statistically significantly increased in patients with severe disability and had a direct mean correlation with the degree of EDSS ( $r s=0.649 ; p<0.05$ ). Among the functional systems with which total spasticity is most associated, pyramidal and bowel/bladder showed the strongest correlations ( $r s=0.712$ and $0.666 ; p<0.05$, respectively).

We performed a correlation and regression analysis of the EDSS scale, pyramidal and bowel/bladder functional systems and total spasticity, which is graphically presented in Fig. 4.

Figure 4 Correlation and regression analysis of EDSS scale, pyramidal, bowel/bladder functional systems and total spasticity

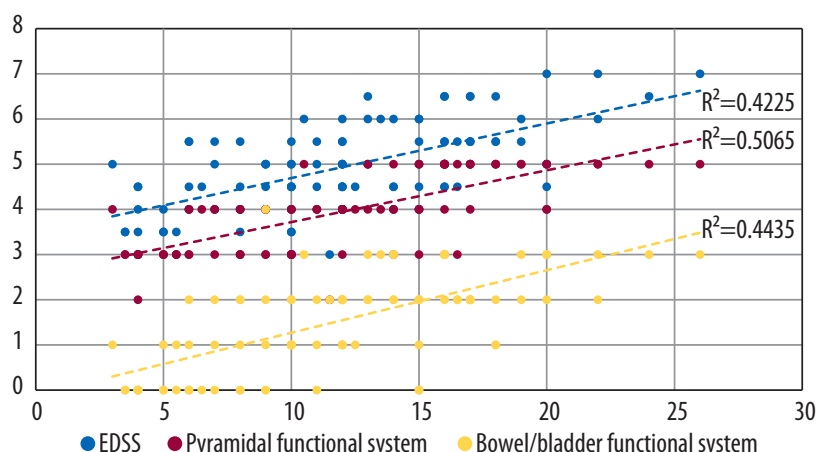

The correlation and regression analysis revealed that the greatest correlation and influence on the level of total spasticity score are caused by the following factors: total EDSS score (coefficient of determination $D=41.0 \%)$, level of disorders in pyramidal $(D=47.0 \%)$ and bowel/bladder functional system ( $D=44.4 \%)$.

Electroneuromyography was performed in 51 patients with MS with signs of spasticity. The average score of spasticity was $1.68 \pm 0.06$ points. Although the vast majority of patients did not have upper extremity spasticity (only $8(16 \%)$ patients had upper extremity spasticity), an electromyographic examination of the upper extremity was performed in all patients to assess the functional status of the muscle fibers. Patients with spasticity of the upper extremities $(n=8)$ had a level of spasticity from 0 to $1+$ points on the MAS (mean score was $0.86 \pm 0.12$ ).

We evaluated the function of $\mathrm{n}$. medianus motor fibers in patients with MS with lower extremity spasticity, depending on the presence or absence of upper extremity spasticity. No significant differences were found in the groups with or without spasticity. There was a tendency of M-latency increase with stimulation of the hand
$(4.86 \pm 0.41 \mathrm{~ms})$ and elbow $(11.03 \pm 0.37 \mathrm{~ms})$ in patients with spasticity. The amplitude of the M-response was lower in patients with spasticity at all points of stimulation: wrist $(10.38 \pm 1.12 \mathrm{mV})$, elbow $(11.03 \pm 0.37 \mathrm{mV})$, armpit $(12.01 \pm 0.53 \mathrm{mV})$ compared to patients who did not have spasticity $(p<0.05)$. It should be noted that the occurrence of the M-response from the muscles is the most common electrophysiological study of motor fibers. M-response is the total potential of muscle fibers, which is registered from the muscle when stimulating the innervating nerve with a single stimulus and can be observed in axonal lesions and may mean a decrease in the number of muscle fibers involved in generating $\mathrm{M}$-response due to conduction disturbances on the part of axons.

Function of $\mathrm{n}$. medianus motor fibers in patients with MS was evaluated depending on the total score of spasticity $\left(1^{\text {st }}\right.$ group - 4-12 points, $2^{\text {nd }}$ group - 13-26 points). There was a significant difference between the indicators in these groups. With stimulation of the elbow area $(11.60 \pm 0.25 \mathrm{~ms} ; \mathrm{p}<0.01)$ and armpit $(12.99 \pm 0.25 \mathrm{~ms} ; \mathrm{p}<0.05)$ in patients with a higher total score of spasticity we saw an increase in M-latency, while the amplitude of the M-response was lower in patients with a higher total score of spasticity at all points of stimulation: wrist $(9.85 \pm 0.58 \mathrm{mV} ; \mathrm{p}<0.03)$, elbow ( $4.27 \pm 0.42 \mathrm{mV} ; \mathrm{p}<0.01)$, armpits $(6.05 \pm 0.78 \mathrm{mV} ; \mathrm{p}<0.01)$. A decrease in the amplitude of the M-response was registered in the absence of clinical manifestations of spasticity in the upper extremities and in the presence of spasticity in the lower extremities. Therefore, a decrease in the amplitude of the M-response may be an early indicator of the development of spasticity. Latency is a time delay from the moment of stimulation to the occurrence of the M-response when the nerve is stimulated at the distal point. Increased latency is characteristic of demyelinating nerve damage. There was a significant increase in M-latency in the elbow and armpits (table 3 ).

Table 3 Evaluation of $\mathrm{n}$. medianus motor fiber function in patients with MS depending on the total score of spasticity

\begin{tabular}{lcccc}
\hline \multirow{2}{*}{ Indicator } & \multirow{2}{*}{ Total score } & \multicolumn{3}{c}{ Stimulation point } \\
\cline { 2 - 5 } & & Wrist & Elbow & Armpit \\
\hline M-latency, ms & $4-12$ & $4.73 \pm 0.34$ & $10.34 \pm 0.36$ & $11.52 \pm 0.34$ \\
\cline { 2 - 5 } & $13-26$ & $4.77 \pm 0.26$ & $11.60 \pm 0.25$ & $12.99 \pm 0.25$ \\
\cline { 2 - 5 } & $p$ & $>0.05$ & $<0.01$ & $<0.05$ \\
\hline M-amplitude, $\mathrm{mV}$ & $4-12$ & $11.19 \pm 0.57$ & $6.43 \pm 0.64$ & $12.89 \pm 3.49$ \\
\cline { 2 - 5 } & $13-26$ & $9.85 \pm 0.58$ & $4.27 \pm 0.42$ & $6.05 \pm 0.78$ \\
\hline Interval, $\mathrm{ms}$ & $\mathrm{p}$ & $<0.03$ & $<0.01$ & $<0.01$ \\
& $4-12$ & $4.98 \pm 0.32$ & $5.71 \pm 0.21$ & $6.73 \pm 3.85$ \\
\hline & $13-26$ & $5.14 \pm 0.24$ & $6.53 \pm 0.16$ & $1.45 \pm 0.17$ \\
\hline Velocity, $\mathrm{m} / \mathrm{s}$ & $\mathrm{p}$ & $>0.05$ & 0.04 & $>0.05$ \\
\hline & $4-12$ & - & $53.43 \pm 2.83$ & $177.43 \pm 23.09$ \\
\hline & $13-26$ & - & $46.01 \pm 1.08$ & $158.57 \pm 30.31$ \\
\hline & $\mathrm{p}$ & - & 0.05 & $>0.05$ \\
\hline
\end{tabular}

$\mathrm{p}$ — significance determined using Mann — Whitney test.

We also evaluated late electrophysiological phenomena - Fwave and $\mathrm{H}$-reflex depending on the presence and absence of spasticity in the upper extremity (Table 4).

According to current data, the F-wave is a motor response of the muscle that occurs periodically during supramaximal stimulation and is physiologically essential to the muscle response to the reverse discharge that occurs as a result of antidromic excitation of the motoneuron. Thus, the parameters of the F-wave characterize the changes in the functional state of the spinal cord motoneurons depending on the degree of spinal and supraspinal exposure. We found significant changes in the latency of the F-wave upon stimulation of $n$. medianus $(p=0.01)$.

F-latency on average increased in patients with spasticity to $62.48 \pm 31.51 \mathrm{~ms}(p=0.04)$. No significant changes in F-amplitude were observed.

The M-response of the muscles of the lower extremity ( $\mathrm{n}$. tibialis motor fibers) was evaluated in patients with MS depending on the 
total score of spasticity, as well as in groups with different mean levels of spasticity.

Table $4 \quad$ F-wave parameters of the upper extremity ( $n$. medianus) in patients with MS depending on the presence of spasticity in the upper extremity

\begin{tabular}{|c|c|c|c|}
\hline Indicator & $\begin{array}{l}\text { Presence }(+) \text { or absence } \\
\quad(-) \text { of spasticity }\end{array}$ & $\begin{array}{c}\text { F-wave } \\
\text { of } n \text {. medianus }\end{array}$ & $\mathbf{p}$ \\
\hline \multirow[t]{2}{*}{ Latency, ms } & + & $2.17 \pm 0.72$ & \multirow{2}{*}{0.01} \\
\hline & - & $4.60 \pm 0.30$ & \\
\hline \multirow[t]{2}{*}{ Amplitude, mV } & + & $7.58 \pm 1.74$ & \multirow{2}{*}{$>0.05$} \\
\hline & - & $8.17 \pm 0.62$ & \\
\hline \multirow[t]{2}{*}{$\mathrm{F}$-frequency, $\mathrm{Hz}$} & + & $61.11 \pm 4.84$ & \multirow{2}{*}{$>0.05$} \\
\hline & - & $49.00 \pm 3.37$ & \\
\hline \multirow[t]{2}{*}{ Average F-latency, ms } & + & $62.48 \pm 31.51$ & \multirow{2}{*}{0.04} \\
\hline & - & $29.77 \pm 0.59$ & \\
\hline \multirow[t]{2}{*}{ Average F-amplitude, mV } & + & $632.78 \pm 98.67$ & \multirow{2}{*}{$>0.05$} \\
\hline & - & $567.79 \pm 71.10$ & \\
\hline
\end{tabular}

$\mathrm{p}$ — significance determined using Mann — Whitney test.

There was a significant decrease in the amplitude of the $M$ response in the ankle in a group of patients with a higher total score of spasticity from $13.73 \pm 1.21 \mathrm{mV}(4-12$ points) to $8.68 \pm 1.06$ $(13-26$ points $)=0.003$ ) and knees from $25.21 \pm 14.49$ (4-12 points) to $3.17 \pm 0.80$ (13-24 points) $(p=0.03)$. Differences in latency were statistically insignificant (Table 5). That is, the M-amplitude is the most sensitive indicator of subclinical manifestations of spasticity.

Table 5 Estimation of $\mathrm{n}$. tibialis motor fiber function in patients with MS depending on the total score of spasticity

\begin{tabular}{lcccc}
\hline \multirow{2}{*}{ Indicator } & $\begin{array}{c}\text { Stimulation } \\
\text { point }\end{array}$ & \multicolumn{3}{c}{ Total spasticity score } \\
\cline { 3 - 5 } & & $\mathbf{4 - 1 2}$ & $\mathbf{1 3 - 2 6}$ & $\mathbf{p}$ \\
\hline M-latency, $\mathrm{ms}$ & Ankle & $7.29 \pm 0.27$ & $7.24 \pm 0.33$ & $>0.05$ \\
\cline { 2 - 5 } & Knee & $16.75 \pm 0.47$ & $17.21 \pm 0.63$ & $>0.05$ \\
\hline M-amplitude, $\mathrm{mV}$ & Ankle & $13.73 \pm 1.21$ & $8.68 \pm 1.06$ & 0.003 \\
\cline { 2 - 5 } & Knee & $25.21 \pm 14.49$ & $3.17 \pm 0.80$ & 0.03 \\
\hline Interval & Ankle & $7.29 \pm 0.26$ & $7.56 \pm 0.28$ & $>0.05$ \\
\cline { 2 - 5 } & Knee & $11.44 \pm 1.34$ & $10.08 \pm 0.41$ & $>0.05$ \\
\hline Velocity, $\mathrm{m} / \mathrm{s}$ & Ankle & - & - & $>0.05$ \\
\cline { 2 - 5 } & Knee & $50.49 \pm 2.60$ & $46.30 \pm 3.36$ & 0.05 \\
\hline
\end{tabular}

$\mathrm{p}$ — significance determined using Mann — Whitney test.

At the same time, evaluation of the latency of $n$. tibialis motor fibers in three groups of patients with different average levels of spasticity showed a significant difference between this indicator in groups of patients and its reduction at the ankle point from $7.78 \pm 0.34$ to $6.95 \pm 0.47$ ( $p=0.018$ ), which is not typical for demyelinating lesions of nerve fibers (Table 6 ).

Table 6 Evaluation of motor fiber function $\mathrm{n}$. tibialis in patients with MS depending on the level of spasticity

\begin{tabular}{|c|c|c|c|c|c|}
\hline \multirow{2}{*}{ Indicator } & \multirow{2}{*}{$\begin{array}{c}\text { Stimulation } \\
\text { point }\end{array}$} & \multicolumn{3}{|c|}{ Level of spasticity } & \multirow{2}{*}{$\mathbf{p}$} \\
\hline & & $0.4-1.4$ & $1.5-2.0$ & $2.1-3.0$ & \\
\hline \multirow[t]{2}{*}{ Latency, ms } & Ankle & $7.78 \pm 0.34$ & $7.05 \pm 0.32$ & $6.95 \pm 0.47$ & 0.018 \\
\hline & Knee & $17.74 \pm 0.64$ & $16.10 \pm 0.55$ & $17.69 \pm 0.44$ & $>0.05$ \\
\hline \multirow{2}{*}{$\begin{array}{l}\text { Amplitude, } \\
\mathrm{mV}\end{array}$} & Ankle & $15.12 \pm 1.67$ & $10.13 \pm 1.11$ & $5.90 \pm 1.20$ & 0.01 \\
\hline & Knee & $20.64 \pm 16.30$ & $16.11 \pm 12.70$ & $4.63 \pm 1.31$ & $>0.05$ \\
\hline \multirow[t]{2}{*}{ Interval } & Ankle & $7.81 \pm 0.34$ & $7.21 \pm 0.29$ & $7.30 \pm 0.39$ & $>0.05$ \\
\hline & Knee & $11.58 \pm 1.51$ & $10.48 \pm 1.19$ & $10.44 \pm 0.57$ & $>0.05$ \\
\hline \multirow[t]{2}{*}{ Velocity, $\mathrm{m} / \mathrm{s}$} & Ankle & - & - & - & - \\
\hline & Knee & $48.26 \pm 3.92$ & $50.25 \pm 2.89$ & $44.36 \pm 2.17$ & $>0.05$ \\
\hline
\end{tabular}

p — significance determined using Mann — Whitney test.

With increasing spasticity, the amplitude of the M-response decreased in proportion to the level of spasticity from 15.12 \pm 1.67 (group $0.4-1.4$ points) to $5.90 \pm 1.20$ (group $2.1-3.0$ points) ( $p=0.01$ ). That is, in patients with severe spasticity, the amplitude of the $M$ response was the lowest.

When assessing the late electrophysiological phenomenon (F-wave) during stimulation of the muscles of the lower extremity (n. tibialis), we found that the average F-latency significantly increased $(p=0.007)$ with increased levels of spasticity in patients (Table 7). Thus, in the group of patients with the lowest level of spasticity (0.4-1.4 points) the average F-latency was $52.93 \pm 1.15 \mathrm{~ms}$, and in the group with the highest level of spasticity (2.1-3.0 points) it was $58.48 \pm 0.91 \mathrm{~ms}$. The average F-amplitude, depending on the level of spasticity, decreased from $621.27 \pm 118.62$ to $476.12 \pm 119.67 \mathrm{mV}$ $(p<0.05)$.

Table $7 \quad$ Indicators of $\mathrm{n}$. tibialis in F-wave patients with MS depending on the level of average spasticity

\begin{tabular}{|c|c|c|c|c|}
\hline \multirow{2}{*}{ Indicator } & \multicolumn{3}{|c|}{ Level of average spasticity } & \multirow{2}{*}{$\mathbf{p}$} \\
\hline & $0.4-1.4$ & $1.5-2.0$ & $2.1-3.0$ & \\
\hline M-latency, ms & $4.40 \pm 0.52$ & $5.19 \pm 0.36$ & $6.18 \pm 0.83$ & $>0.05$ \\
\hline M-amplitude, mV & $3.92 \pm 0.81$ & $6.78 \pm 1.09$ & $8.56 \pm 0.95$ & 0.008 \\
\hline F-frequency, $\mathrm{Hz}$ & $78.85 \pm 4.72$ & $65.53 \pm 4.80$ & $74.62 \pm 8.82$ & $>0.05$ \\
\hline Average F-latency, ms & $52.93 \pm 1.15$ & $53.38 \pm 1.14$ & $58.48 \pm 0.91$ & 0.007 \\
\hline Average F-amplitude, mV & $621.27 \pm 118.62$ & $487.97 \pm 79.44$ & $476.12 \pm 119.67$ & $<0.05$ \\
\hline
\end{tabular}

$\mathrm{p}$ — significance determined using Mann — Whitney test.

We investigated the H-reflex, which is associated with a descending inhibitory effect of the brain on the spinal cord. There was a tendency of decrease of M-latency, increase of the maximum $\mathrm{H}$ with increasing spasticity. But the difference in the groups of patients was insignificant.

Thus, in patients with MS of different levels of spasticity, a significant decrease in the amplitude of the M-response was found in the study of both upper and lower extremities, which means a decrease in muscle fibers involved in the generation of M-response due to conduction in axons. This indicator is the most sensitive indicator of early manifestations of spasticity. Its changes were registered in patients with minimal clinical manifestations of spasticity. While indicators of late electrophysiological phenomena (F-wave), especially average F-amplitude, changed in patients with spasticity only on the lower extremities, M-latency rates were significantly increased in patients with spasticity of the upper extremities at two points of stimulation. M-latency in the lower extremities was significantly reduced, which is not characteristic of demyelinating nerve damage and requires further study. Depending on the presence of spasticity in the upper extremities, the average F-latency on the upper extremities (F-wave) increased significantly. At the same time, a significant decrease in M-latency (F-wave) in the upper extremities and latency of the M-response in the lower extremities was recorded, which indicates the sensitivity of this indicator from other factors.

\section{Conclusions}

1. The highest values of average spasticity are observed in patients with SPMS $(p<0.01)$, while pyramidal and bowel/bladder functional systems have the strongest correlation with the level of total spasticity ( $r s=0.712$ and $0.666 ; \mathrm{p}<0.05$ respectively).

2. Among the muscle groups of the lower extremities, the average score of spasticity in patients with MS is the highest in the knee extensors at SPMS $-2.49 \pm 0.19$ points, and the lowest in patients with RRMS for foot flexors $-1.08 \pm 0.06(p<0.01)$.

3. Latency rates can both increase and decrease in patients with different levels of spasticity.

4. The main electrophysiological indicator of early manifestations of muscle spasticity of the upper and lower extremities in patients with MS is a decrease in the amplitude of the M-response $(p<0.01)$.

Conflict of interests: the author declare no conflict of interests. 
References:

1. Schapiro R.T. (2007) Managing the Symptoms of Multiple Sclerosis, $5^{\text {th }}$ ed., Demos Medical Publishing, $192 \mathrm{p}$.

2. Ivko 0.L., Prakhova L.N., Tsvetkova T.L. et al. (2007) Features of movement disorders in multiple sclerosis and methods of their drug correction. Neuroimmunology, 1(2): 37-45 (In Rus.).

3. Barnes M.P., Kent R.M., Semlyen J.K. et al. (2003) Spasticity in multiple sclerosis. Neurorehabilitation and neural repair, 17(1): 66-70. https://doi.org/10.1177/0888439002250449

4. Shakespeare D., Craig J., Lloyd M. (2001) Spasticity and Movement. Int. MS J., 7(3): 93-99.

5. Milinis K., Tennant A., Young C. A. et al. (2016) Spasticity in multiple sclerosis: Associations with impairments and overall quality of life. Multiple sclerosis and related disorders, 5:34-39. https://doi.org/10.1016/.j.msard.2015.10.007

6. Nielsen J.B., (rone C., Hultborn H. (2007) The spinal pathophysiology of spasticity from a basic sciencepoint ofview.ActaPhysiologica(0xford), 189:171-180.D0l:10.1111/j.1748-1716.2006.01652.x

7. Biering-Sørensen F., Nielsen J. B., Klinge K. (2006) Spasticity-assessment: a review. Spinal cord, 44(12): 708-722. https://doi.org/10.1038/sj.sc.3101928

8. Mitchell A.J., Benito-León J., González J.M. et al. (2005) Quality of life and its assessment in multiple sclerosis: integrating physical and psychological components of wellbeing. Lancet Neurol., 4(9): 556-566. https://doi.org/10.1016/S1474-4422(05)70166-6-566

9. Voerman G.E., Gregoric M., Hermens H.J. (2005) Neurophysiological methods for the assessment of spasticity: The Hoffmann reflex, the tendon reflex, and the stretch reflex. Disabil. Rehabil., 27(1-2): 33-68. D0I: 10.1080/09638280400014600

10. Hoang P.D. (2009) Spasticity and Multiple Sclerosis. MS Practice (Australia) (https://www. msaustralia.org.au/file/278/download?token=cK4rr3lc).

11. Thompson A.J., Banwell B.L., Barkhof F. et al. (2017) Diagnosis of multiple sclerosis: 2017 revisions of the McDonald criteria. Lancet Neurol., DOl:10.1016/S1474-4422(17)30470-2

12. Kurtzke J.F. (1983) Rating neurologic impairment in multiple sclerosis: an expanded disability status scale (EDSS). Neurology, 33: 1444-1452. DOI: 10.1212/wnl.33.11.1444

13. Kurtzke J.F. (1998) On the evaluation of disability in multiple sclerosis. Am. Acad. Neurol., 11: 686-694. DOI: 10.1212/wnl.11.8.686

14. Kurtzke J.F. (2008) Historical and clinical perspectives of the expanded disability status scale. Neuroepidemiology, 31: 1-9. D01: 10.1159/000136645

15. Ashworth B. (1964) Preliminary trial of carisoprodol in multiple sclerosis. The Practitioner, 192: 540-542. PMID: 14143329

16. Bohannon R.W., Smith M.B. (1987) Interrater reliability of a modified Ashworth scale of muscle spasticity. Physical. Ther., 67(2): 206-207 (https://doi.org/10.1093/ptj/67.2.206)

17. Nance P.W., Sheremata W.A., Lynch S.G. et al. (1997) Relationship of the antispasticity effect of tizanidine to plasma concentration in patients with multiple sclerosis. Arch. Neurol., 54: 731-736. DOI: 10.1001/archneur.1997.00550180049011

\section{Відомості про автора:}

Домрес Наталія Вадимівна — заочний аспірант кафедри неврології Національного медичного університету імені 0.0. Богомольця, лікар-невролог відділення демієлінізуючих захворювань KHП «Київська міська клінічна лікарня № 4», Київ, Україна. ORCID ID: 0000-0001-9771-4146 Адреса для кореспонденції:

Домрес Наталія Вадимівна

03110, м. Київ, вул. Солом'янська, 17

E-mail:nata003@ukr.net

\section{Клініко-електрофізіологічні особливості спастичності у хворих на розсіяний склероз}

\section{Н.В. Домрес}

Національний медичний університет імені О.О. Богомольця, Київ, Україна

Анотація. Мета: Визначення взаємозв'язків клінічних та електрофізіологічних особливостей спастичності у хворих на розсіяний склероз. Об'єкт і методи дослідження. Обстежено 100 пацієнтів із розсіяним склерозом зі спастичністю. Для кількісної оцінки вираженості змін м'язового тонусу застосовували модифіковану шкалу Ешворта (Modified Ashworth Scale). Електронейроміографію проводили на апараті «Nihon Kohden» з використанням стандартної стимуляційної неінвазивної методики у ділянках верхніх та нижніх кінцівок. Результати. Рівень середньої спастичності у хворих за модифікованою шкалою Ешворта становив 0,4-3,0 бала. Виявлено, що у трьох досліджуваних групах різного типу перебігу розсіяного склерозу рівень спастичності окремих груп м'язів достовірно відрізнявся. Рівень сумарної спастичності у хворих на розсіяний склероз статистично достовірно збільшувався в осіб із вираженим ступенем інвалідизації та мав прямий середній корелятивний зв'язок зі ступенем за розширеною шкалою ступеня інвалідизації (Expanded Disability Status Scale) ( $r s=0,649 ; p<0,05)$. При оцінці функції рухових волокон n. medianus i n. tibialis виявлено достовірні зміни М-амплітуди. Висновки. Найбільші значення середньої спастичності виявляли у хворих на вторинно-прогресуючий розсіяний склероз, пірамідна і тазова функціональні системи мають найсильніший кореляційний взаємозв'язок з рівнем сумарної спастичності ( $r s=0,712$ та 0,666; $p<0,05$ відповідно). Серед груп м'язів нижніх кінцівок середній бал спастичності найвищий у розгиначах коліна при вторинно-прогресуючому розсіяному склеро-

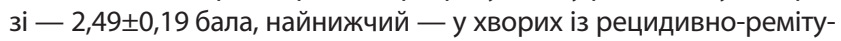
ючим розсіяним склерозом для згиначів стопи - 1,08 $\pm 0,06$ ( $<<0,01)$. Основним електрофізіологічним індикатором ранніх проявів спастичності м'язів верхніх і нижніх кінцівок у хворих на розсіяний склероз $є$ зниження амплітуди М-відповіді $(\mathrm{p}<0,01)$.

Ключові слова: розсіяний склероз, спастичність, модифікована шкала Ешворта, електронейроміографія, М-амплітуда.

\section{Information about the author:}

Domres Nataliia V. — extramural graduate student of the Department of Neurology of the 0.0. Bohomolets National Medical University, neurologist of the Department of Demyelinating Diseases of the Kyiv City Clinical Hospital No. 4., Kyiv, Ukraine. ORCID ID: 0000-0001-9771-4146

Address for correspondence:

Nataliia Domres

03110, Kyiv, Solomianska str., 17

E-mail:nata003@ukr.net 